\title{
A Publication Profile Of Accounting Faculty
}

Stephen Kerr, Bradley University, USA

Mark G. Simkin, University of Nevada Reno, USA

Richard Mason, University of Nevada Reno, USA

\begin{abstract}
The authors surveyed the faculty teaching in AACSB-accredited accounting programs and examined how their publication rates varied by years-after-completing-dissertation, professorial rank, major research area, type of degree-granting institution, and gender. Using standard statistical methods, the authors found that only "years-after-completing-dissertation" and "gender" were statistically significant, but care must be exercised in interpreting these results.
\end{abstract}

Keywords: Publication, Accounting Faculty, Academic Productivity, AACSB, Merit, Tenure

\section{INTRODUCTION}

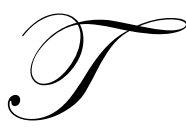

he three measures that are generally used to evaluate a faculty member's overall performance for merit, tenure, or promotion awards are teaching, research, and service. Of these three metrics, many institutions use "research productivity" as the preeminent determinant of salary awards and promotions. However, because universal guidelines have yet to be developed that differentiate between various levels of research productivity, this area remains ripe for academic exploration.

Within the accounting discipline, research on publication rates-really meta research-enjoys special interest. One reason for this is because the accounting area is a business discipline, and therefore, an area in which applied research is more important to academics than it is to related business areas such as finance. Another reason is because many accounting faculty closely identify themselves with the vocational interests of their students, and therefore prefer to devote more time to their teaching, rather than research, responsibilities. But these considerations can produce complications when administrators compare accounting research productivity to the research produced in other disciplines. If accountants do in fact publish less than the faculty in other disciplines, target their writing toward more practitioner journals, or in some other way distinguish themselves in their publication profiles from other faculty, then these individuals must develop their own research norms and create their own measures of performance.

The purpose of this study was to develop a profile of the publication rates of accounting faculty, differentiated by the professor's area of research specialization, rank, years-after-completing-dissertation, and gender. Like predecessor studies, these rates in turn are useful in developing normative levels of research performance. Thus, our goal was to examine the publication rates of accounting faculty in order to create benchmarks that might be useful to individuals wishing to evaluate their own publishing efforts, and that also might be useful to administrators wishing to compare an instructor's academic research performance to others in the field.

\section{MEASURING RESEARCH PRODUCIVITY IN ACCOUNTING}

There are many reasons why measures of research productivity are important to accounting faculty. Probably foremost among them is an interest in creating benchmarks for the quantity and quality of publications needed to obtain tenure, be promoted, or receive annual merit awards (Hasselback, et. al, 2000; Hult, et. al., 1997, Pierce and Garner, 1995; Hagerman and Hagerman, 1989) Then too, administrators have a similar interest in these norms because these individuals seek guidance in making such tenure, promotion, and merit decisions, and also because they tend to play an important role in hiring decisions (Maranto and Streuly, 1994; Campbell, et. al., 1983; Schultz, et. al., 1989). 
Faculty research productivity is also important to those universities and colleges seeking accreditation (Bublitz and Kie, 1984; Hasselback, 2000). In particular, the AACSB and similar accreditation agencies require metrics with which to gauge the research productivity of those schools having notable research expectations in their mission statements.

Measures of research productivity are also commonly used for comparative purposes. One application in the accounting area is for comparisons among similar institutions (Lucertini, 1995; Posy and Parker, 1989; Jacobs, et. al., 1986), comparisons between Ph.D. and non-Ph.D. granting institutions (Schultz, et. al, 1989), or studies seeking to identify the accounting profession's most prolific researchers (Hech and Bremsyn, 1986; Hech, et. al, 1991; Gopolakrishan and Chandy, 1991).

Research output has also been germane to studies comparing productivity by accounting area. For example, prior studies that segregated accounting faculty publications by accounting specialization have found that the median number of articles published is slightly correlated to area of specialization. (Campbell and Morgan ,1987; Englebrecht, et. al.,1994). Both of these studies determined that, on average, accounting faculty categorized as primarily specializing in tax research tend to publish more articles than their counterparts specializing in other accounting areas.

A third comparative application has been in gender studies of research productivity. Cole and Zuckerman (1984) note, for example, that over 50 such studies of academics outside the accounting discipline have found that female faculty members publish significantly fewer articles than their male counterparts. In a later study, Zuckerman (1987) found that women publish between 50 and 60 percent as many papers of what men publish.

Do these gender differences apply in the accounting area and in the new millennium? Two recent studies have sought to answer this question. Streuly and Maranto [1994] found that, when comparable sets of one male and one female faculty members were paired in conjunction with three common measures of professional background (Ph.D., year, institution granting the degree, and initial appointment [doctoral-granting vs. non-doctoral-granting institution]), men published slightly more articles across the various permutations of these criteria, but that these differences were not statistically significant. Dwyer [1994] found that when all doctoral recipients from 1981 who worked as academics (per Hasselback's Accounting Faculty Directory) were compared, women had published fewer times in academic journals, but had achieved comparable levels of academic impact (per citation counts) and had published virtually equal amounts of articles in "professional" accounting journals.

A final comparative application has been to measure differences in research expectations over time. A number of such studies suggest that these expectations are increasing, and that higher publication standards are now in place (Read, Rama, and Raghunandan, 1998; Zivney, 1995; Milne and Vent, 1987, Englebrecht, et. al, 1994).

Measuring research productivity is easier to discuss than it is to do. The key problem has been finding a suitable metric. The authors know of no study, for example, that has included counts of "conference proceedings, "working papers," or "works in progress" as part of a performance measure. Yet, ignoring such efforts also requires researchers to discount such items as completed papers (even though some conference papers are blind refereed in screening processes every bit as discriminatory as journal evaluations), grant applications (despite the benefits such work provides to the recipients), or papers that have been accepted in journals that subsequently fail (and thus do not get published, even though they have passed the same screening tests as published papers).

For the reasons cited above, the most popular measure of "research productivity" has been counts of those papers published in "premier" journals (Van Fleet, et. al., 2000, Hasselback, et. al., 2000). However, this method begs the question of which journals to use for the analysis. In the last few years, several studies have attempted to identify the quality or academic impact of various accounting publication outlets in order to identify a suitable list (Hasselback, et. al., 2000; Heck, et. al, 1990 and 1991).

One problem with the use of journals lists with which to measure accounting researcher productivity is that the lists have not been consistent from study to study, or even within the same study (see, for example, Zivney, et. al., 1995). Another problem is that accounting professionals often publish papers in quality journals that are outside 
their immediate discipline and whose journal titles therefore may not appear in the journals on the "count lists" created for this task. In the area of accounting information systems, for example, Daigle and Arnold (2000) found that the "top 25 AIS researchers" developed a journal hierarchy in which the third, fourth, fifth, and seventh-rated journals were non-accounting publication outlets. Subsequent work by Christiansen, et. al., (2002) suggests that the tendency to publish outside the immediate discipline is pervasive, averaging over a half an article per year for the accounting Ph.D.'s in that study's researcher cohort.

Productivity researchers are also sensitive to the problem of co-authorship-for example, the fact that (without adjustment) an individual who has coauthored three papers will have three times the number of publications of an individual who has sole authored only one paper (and perhaps expended an equal amount of work). Recently, several investigators have attempted to further refine this process by adjusting for such factors as co-authorship (Hasselback, et. al., 2000) or accounting specialty (Campbell and Morgan, 1987), or have opted to use "citations" instead of "authorship" to better measure of research quality (Alexander and Mabry, 1994; Brown and Gardner, 1985).

Finally, some authors argue that the type of program in which a faculty member works limits or enhances his or her ability to perform research, thus making research norms also dependent upon the type of academic environment in which researchers find themselves. This idea has not escaped scholars, who have therefore tried to adjust for this in an interest in "leveling the playing field" (Englebrecht, et. al, 2000, Read, et. al., 1998, Dwyer, 1994, Schultz, et. al., 1989). Thus, a third strand of research has attempted to compare the publication trends of faculty at institutions that grant doctoral degrees with faculty from institutions that do not grant doctoral degrees, or in a similar vein, accredited (i.e. by the AACSB) with unaccredited schools-research that helps quantify productivity levels under varying levels of publication expectations. In the opinion of the authors, this is a testable hypothesis rather than an automatically-relevant distinction.

\section{A NEW SURVEY}

Many of the studies cited above are now at least ten years old or used statistical methods that some scholars suggest hide more than they show. To answer the question of whether these findings are still valid, the authors decided to perform a new study. We began by identifying all accounting schools that are separately-accredited by the Association to Advance of Collegiate Schools of Business (AACSB), using the web site at http://www.aacsb.edu. We sent a packet of survey instruments (Appendix A) to the chairperson of the accounting department at each of these schools, requesting that this individual in turn distribute them to the faculty members in their departments. We also included self-addressed, stamped envelopes for each survey. The number of instruments sent and the address for each school were based on the faculty and school listings in Prentice Hall's Accounting Faculty Directory 2001-2002 (Hasselback's).

To measure research productivity, we asked each respondent to provide us with information about the total number of blind-refereed articles they had published to date, their area of research specialization, their gender, their academic rank, the number of years that had passed since completing their doctorate, and what academic accounting programs were offered at the respondent's school. The areas of research specialization were (1) accounting information systems (AIS), (2) auditing, (Audit), (3) financial accounting (Financial), (4) managerial accounting (Management), (5) tax accounting (Tax), and (6) other (Other). The Other category captured all responses that did not list the first five areas above, and included governmental and not-for-profit accounting, international accounting, accounting education, and ethics.

Our academic rank categories were (1) Adjunct Professor, (2) Assistant Professor, (3) Associate Professor, (4) Full Professor, and (5) Other. The years since completion of doctorate information was requested to provide a scaling variable to effectively compare the productivity levels reported. The information on different academic accounting programs offered at the school was requested to ascertain if various levels of program offerings affected research productivity.

We sent a total of 2,497 survey instruments, and received a total of 205 responses, resulting in a response rate of $8.2 \%$. Reflective of the profession, we received 152 responses from male respondents and 53 responses from 
female respondents - a ration of $74 \%$ males and $26 \%$ females. Also, of these 205 individuals, 18 listed their primary area as AIS. The corresponding numbers for other sub-disciplines were Audit (38), Financial Accounting (64), Managerial Accounting (37), and Tax (18). A total of 27 respondents classified themselves as "other."

Almost all of the respondents worked in accounting schools that offered a master's degree of some type. Of the 205 respondents, 108 reported that they worked at institutions granting Ph.D.'s in accounting, while 95 reported that they worked at institutions not granting such terminal degrees.

\section{DATA ANALYSIS AND RESULTS}

We entered the information from the survey instruments into a computerized data set. Auditing of the entered data resulted in an approximate error rate of $.2 \%$ for the $15 \%$ of the data subjected to random review. The two data-entry errors found were corrected. Data analysis was performed using SHAZAM version 9 econometrics package.

The first panel of Table 1 provides mean publication rates for all faculty combined, separated by area of research specialization and gender. These results reflect the reported number of peer-reviewed publications divided by the number of respondents reporting that specialization. Thus, the first panel of Table 1 provides the combined results for all 202 of the tenured or tenure-track faculty (i.e. assistant, associate, and full professors) who completed our survey.

The overall mean publication rate was 15.4 articles per capita. This means that that the average accountant in our survey, regardless of rank, years of service, or gender, had published over 15 blind-refereed articles to date. We note here that two male respondents each reported in excess of 100 blind-refereed publications. Although we have no reason to doubt the veracity of the information these individuals reported, we omitted their entries from the data set in order to avoid these two outlying publication rates impacting our overall results. Thus, the figures in Table 1 do not include these two survey responses.

The specialization areas of auditing and tax produced the highest publication rates, each with 17.0 publications per capita, while management accounting had the lowest publication level of 11.5 publications per capita. In Panel 1, we also note that male respondents had an overall mean rate of 18.0 publications per person, compared to female respondents of 8.6 publications. This gender differential is consistent with earlier studies, and exactly mimics Zuckerman's findings that women publish about 50 percent as much as men do (Zuckerman, 1987). But is it possible that there are a relatively larger number of females in the lower academic ranks, and perhaps have merely lacked the time to publish? We examine this question in greater detail below.

Panels 2, 3, and 4 of Table 1 provide mean publication rates for accounting faculty, by specialty within faculty rank. For example, Panel 2 shows that the average publication rate for all assistant professors was 3.9 articles, while the corresponding figure for associate professors was 11.6 articles and for full professors was 28.0 articles. We found that this pattern of increasing mean publications by rank held for the total rows within each and every discipline of the profession - a consistent, if intuitive, observation, because most AACSB- accredited schools require publications for promotion to higher ranks. But this finding also provides evidence for this.

Panels 2, 3, and 4 also indicate that the mean number of publications reported for all male faculty members (i.e., in the columns labeled "All") was higher at each rank than for female faculty. For example, the mean number of publications was 4.7 for male assistant professors compared to "2.7" for female assistant professors. The values for associate professors were "12.6" (for males) versus " 8.5 " (for females), and for full professors was "29.0" (males) versus "22.6" (females).

These results suggest that the gender differential in mean total publications that we observed in Panel 1 cannot be explained by the fact that a higher percentage of the females answering our survey happened to be assistant professors with a smaller number of publications. We also note that these gender differences appear to apply across the sub-disciplines of accounting, with the notable exception of AIS Assistant professors and Managerial Full professors - the two areas in which females out-published males. However, the number of 
respondents in both these categories is small ( 5 respondents in total for the AIS category and 1 respondent for the female Managerial category), making generalizations difficult.

A number of factors are likely to affect the publication rates of accounting faculty. One of the most important is employment longevity - i.e., the length of time that has passed after receiving a doctorate. To ascertain whether the lower numbers of publications reported by female accountants is indicative of the fact that women have only recently had increased numbers in the profession, we scaled the number of publications reported by the number of years since the respondent completed his or her doctorate. This analysis results in the mean publication rates per year shown in Table 2.

The first panel in Table 2 shows the mean publication rates, per year, for all faculty ranks combined. Perhaps the most important value in this panel is the overall rate of "1.08." This means that, regardless of rank, gender, or type of school, the respondents in our survey reported an average publication rate of slightly more than one blind-refereed paper per year. We also observed that the overall rates for the individual sub-disciplines varied from low publication rates of .85 articles per year for tax specialists and .89 articles per year for managerial accountants, to high rates of 1.31 articles per year for audit specialists and 1.22 articles per year for AIS accountants. All four of these rates differ significantly from the overall computed mean rate of 1.06 articles per year (alpha $=$ .05 ). This finding suggests that the research outputs of the various accounting specialties are inconsistent across the sub-disciplines.

The lower rows in Panel 1 of Table 2 display the mean publication rates of accounting faculty, separated by gender. As before, the mean overall productivity of male researchers (1.15) exceeded that of females (.88), and is statistically significant $(\mathrm{alpha}=.01$ ). These publication rates also suggest that the differential values computed for male and female accounting researchers observed in Table 1 cannot be attributed to smaller times in rank for female accountants. We also note that this gender difference is not consistent across all sub-disciplines, however, and that female AIS and tax specialists out-published their male counterparts in both areas.

Panels 2, 3, and 4 in Table 2 show the mean publication rates for assistant professors (Panel 2), associate professors (Panel 3), and full professors (Panel 4). At all ranks, the overall publication rates for male respondents was higher than those for female respondents. The greatest difference, .38 publications per year, appears at the associate professor level and shows that the male respondents publish about $1 / 3$ of a paper more per year than female respondents. At the assistant professor level the difference exists but is somewhat less, .20 publications per year. Interestingly, at the full professor the difference is quite small, .08 publications per year (1.22-1.14), or about $1 / 12$ of a publication per year.

In all these panels, we note that the differences in mean publication rates are mostly small, ranging from a high rate of 2.22 for female Assistant professors in AIS, to a low of .36 articles per year for female Managerial accountants. Again, the small numbers of respondents in each of these cells makes generalizations difficult, but the absence of very large or very small publication rates in any cell in the first row of each panel suggests that research productivity is fairly consistent across the accounting sub-disciplines.

There are many factors beyond gender or employment longevity that can potentially affect research productivity. One of the most commonly cited influences is the presence of a $\mathrm{Ph} . \mathrm{D}$. program in the curriculum, which potentially signals higher publication expectations as well as serves as a surrogate for the presence of the resources necessary to perform high-quality research. Because we asked whether or not such a program existed at each respondent's school, this was a testable hypothesis that we attempted to answer using standard linear regression techniques.

Table 3 shows the results of our analyses. In this table, "publication rates" (publications per year) was the dependent variable and the independent variables included "gender," the number of years after receiving a doctorate, whether the respondent's school had a Ph.D. program (as a dummy, 0-1 variable), and the "area of research specialization" (coded as 0-1 dummy variables). The regression analysis was performed for all respondents taken as one same, and then separately for each rank: assistant, associate and full professorial ranks. 
Looking first at the regression results for all professors (line 1 in Table 3), we found that the presence of a $\mathrm{Ph} . \mathrm{D}$. program was not significant, nor were any of the other independent variables - except the "number of years after receiving a doctorate." The coefficient of this variable of " 1.04 " is also meaningful, confirming our earlier finding that an accounting faculty member publishes about one article per year.

We mostly found these same results for the linear regressions in the remaining lines of Table 3 , in which we controlled for faculty rank. However, for an alpha level of .05, we noted that the presence of a Ph.D. program was statistically significant for associate professors, and in addition, that there was a significant gender difference at both the assistant professor level $(\mathrm{t}=2.24)$ and associate professor level $(\mathrm{t}=2.34)$, but not at the full professor level $(\mathrm{t}=.80)$. The variable for the "number of years after receiving a doctorate" continued to be statistically significant in all three regressions, but we also noted the curious decrease in the coefficient for this variable. We attributed this observation to the presence of gender differences (for assistant professors), significant research productivity of financial accountants (for associate professors), and significant research productivity for audit specialists (for full professors).

Because of these latter findings, we also ran a second series of regressions for three popular accounting specializations: financial accounting, auditing, and managerial accounting. Table 4 shows the results of this analysis. Here, gender differences were not statistically significant at any rank, but "years after receiving doctorate" (favorably) mattered for all three specializations.

Finally, we note that none of our linear regressions were able to explain more than 43 percent of the variability in research productivity of our sample accounting faculty, and that most of our models performed substantially below this level. Although we would have welcomed higher r-squares, these results are not uniformly unfavorable. In particular, they suggest that, while "gender" and "presence of a Ph.D. program" appear to affect research productivity, they are not overwhelming determinants of such productivity. Consequently, we hypothesize that a host of additional factors beyond those tested here also affect research productivity-for example, family responsibilities at home, university teaching loads, or even innate ability.

\section{CAVEATS}

The results presented here should be interpreted with care. One caveat is the fact that this study used selfreported data. And although we do not doubt the professional integrity of our colleagues, we must admit the possibility that some respondents erred in reporting their total number of publications or underestimated the number of years that have passed since completing their dissertation, or even made mistakes in stating their age. We must also admit the likelihood that even the most straightforward questions can be ambiguous under certain circumstances - for example, there will arise some question about how to classify one's school if it recently installed or discontinued a Ph.D. program.

Another matter is the fact that we asked respondents for the number of blind-refereed papers they had published since receiving their doctorate. The wording of this question therefore had the effect of not counting any publications a respondent had prior to receiving their terminal degree. Inasmuch as many doctoral students now publish papers prior to completing their doctorate, this matter causes our study to underestimate the total number of publications per faculty member, and their subsequent publication rates. A related matter is the possibility that at least some of the respondents did not immediately work in academia, but instead spent time in industry where publishing academic papers was not important.

Another third problem is the possibility that our statistics do not accurately reflect the research productivity of the underlying population from which it was drawn. Although this difficulty plagues any sampling system, it is easy to speculate that a number of specific problems were at work in this study. One idea is the possibility that the most productive researching faculty - a disproportionate percentage of whom were women-were too busy performing their own research to complete our survey. A counter-argument is that the authors chose to omit two outliers from their analyses precisely because each of them claimed to have published in excess of 100 articles in relatively short periods of time (and thus the results are conservative). Conversely, it is also possible that the least- 
productive faculty did not have any publication activity to report and thus chose not to complete our questionnaire, also skewing our results.

A third difficulty is the fact that this study made no adjustments for "coauthorship" in its research productivity measure. Although many schools do not distinguish between "sole authorship" or "coauthorship" when making personnel decisions, it is also true that three publications, each written by exactly three scholars, would count as "three publications" in this study, whereas one, sole-authored publication would count as "one publication."

A similar difficulty applies to the issue of "research quality"-i.e., the idea that "high-quality" publications should count more than "low-quality" papers, even if both are published in recognized publication outlets. This problem has led many scholars to make distinctions between academic and practitioner-oriented journals, hard-copy versus electronic journals, peer-reviewed versus internally-reviewed publications, or journals whose policies first require conference presentations at regional or national meetings. For these reasons, some studies have purposely limited their publication counts to the "top accounting journals" identified in prior alternate studies. Counterarguments include the idea that many schools recognize publications in conference proceedings or less-thantop journals as legitimate research scholarship, the fact that a surprising number of tenured faculty do not publish anything using any measure of performance, and that this study was more concerned in explaining the differences in scholastic productivity rather than the absolute quality of it.

Finally, it can be argued that expectations regarding research scholarship have increased over time, thereby placing a greater burden on junior faculty to publish than was true in the past. It also creates a moving target, making it difficult to establish publication norms that accurately reflect research expectations for more than brief periods of time. A similar argument is that full professors have less incentives to perform research than their junior brethren because there are no further promotional levels, or little merit rewards, to do so. This can explain, for example, why senior accounting faculty sometimes have smaller publication records, yet higher ranks, than the junior faculty at the same school. We note, however, that we did not find evidence for this in our own study.

\section{CONCLUSIONS}

The results of our survey provide several tentative benchmarks for accounting faculty. One useful set of values is the total number of publications, by rank, for accounting faculty-i.e., about four articles for assistant professors, 11.6 articles for associate professors, and 20 articles for full professors. A second benchmark is the overall publication rate of almost exactly one blind-refereed journal publication per year. This value appears to vary very little among the accounting sub-disciplines, and therefore seems a reasonable target for accounting faculty at AACSB-accredited schools.

A second important finding is the continued significance of "gender" as an important factor that influences publication rates. Our analysis suggests that this differential is pervasive, affecting accounting faculty publication rates at the lower academic ranks and across at least some of the accounting sub-disciplines. It is also likely to disappoint those who argued ten years ago that female accountants have merely needed more time to "catch up" to their male counterparts and reach publication parity.

Finally, within the confines of the sample at hand, a third finding was the lack of evidence to support the claim that the presence of $\mathrm{Ph}$.D. programs positively affect research productivity. Our analysis in fact showed the opposite-i.e., that the presence of such programs has no detectable impact on publication rates, with the possible exception of those faculty working at the associate professor rank. Again, we note that we made no adjustments for research quality (other than limiting our publication counts to blind-refereed articles), coathorship, or similar concerns, but realize that such matters may be important in those schools with high research expectations.

\section{REFERENCES}

1. Alexander, John C., Jr., and Rodney H. Mabry "Relative Significance of Journals, Authors, and Articles Cited in Financial Research" Journal of Finance vol. 49, no. 2 (June, 1994), pp. 697-712. 
2. Brown, Lawrence D. and John C. Garnder "Applying Citation Analysis to Evaluate the Research Contributions of Accounting Faculty and Doctoral Programs" The Accounting Review vol. 60, no. 2 (April, 1985), pp. 262-276.

3. Brown, Lawrence D. and John C. Gardner "Using Citation Analysis to Assess the Impact of Journals and Articles on Contemporary Accounting Research” Journal of Accounting Research vol. 23, no. 1 (Spring, 1985), pp. 84-109.

4. Campbell, David R. and Robert G. Morgan "Publication Activity of Promoted Accounting Faculty" Issues in Accounting Education (Spring, 1987), pp. 28-43.

5. Christensen, Anne L. Catherine A. Finger, and Claire K. Latham, "New Accounting Scholars' Publications in Accounting and Nonaccounting Journals," Issues in Accounting Education vol. 17, no. 3 (Aug, 2002), pp. 233-238.

6. Daigle, Ronald J. and Vicky Arnold "An Analysis of the Research Productivity of AIS Faculty" International Journal of Accounting Information Systems vol.1, no. 2 (Sept, 2000), pp. 106-122.

7. Dwyer, Peggy D. "Gender Differences in the Scholarly Activities of Accounting Academics: An Empirical Investigation” Issues in Accounting Education (Fall, 1994), pp. 231-243.

8. Englebrecht, Ted D., Govind S. Iyer, and Denise M. Patterson "An Empirical Investigation of the Publication Productivity of Promoted Accounting Faculty” Accounting Horizons (March, 1994), pp. 45-68.

9. Hasselback, James R., Alan Reinstein, and Edward S. Schwan "Benchmarks for Evaluating the Research Productivity of Accounting Faculty” Journal of Accounting Education (June, 2000), pp. 79-97.

10. Hasselback, J. R., and Alan Reinstein "A Proposal for Measuring Scholarly Productivity of Accounting Faculty” Issues in Accounting Education (Fall, 1995), pp. 269-306.

11. Hasselback, James R. and Alan Reinstein “Assessing Accounting Doctoral Programs by Their Graduates' Research Productivity” Advances in Accounting( 1995), pp. 61-86.

12. Hult, G. Thomas M., William T. Neese, and R. Edward Bashaw "Faculty Perceptions of Marketing Journals" Journal of Marketing Education (Spring, 1997), pp. 37-52.

13. Heck, J. L., R.E. Jensen, and P. L. Cooley "An Analysis of Contributors to Accounting Journals" International Journal of Accounting Education Part I vol. 25, no. 1 (1990), pp. 202-217, Part II vol. 26, no. 1 (1991), pp. 1-17.

14. Maranto, Cheryl L. and Carolyn A. Streuly “The Determinants of Accounting Professor's Publishing Productivity - the Early Career” Contemporary Accounting Research (Spring, 1994), pp. 387-407.

15. Pierce, Barbara and Garnet Garven, "Publishing International Business Research: A Survey of Leading Journals” Journal of International Business Research vol. 26, no. 1 (1995), pp. 69-89.

16. Read, William J., D. V. Rama, and K. Raghunandan “Are Publication Requirements for Accounting Faculty Promotions Still Increasing? Issues in Accounting Education (May, 1998), pp. 328-339.

17. Schultz, Joseph J. Jr., Janet A. Meade, and Inder Khurana "The Changing Roles of Teaching, Research, and Service in the Promotion and Tenure Decisions for Accounting Faculty" Issues in Accounting Education (Spring, 1999), pp. 109-119.

18. Streuly, Carolyn A. and Cheryl L. Maranto "Accounting Faculty Research Productivity and Citations: Are there Gender Differences?” Issues in Accounting Education (Fall, 1994), pp. 247-255.

19. Van Fleet, David D., Abagail. McWilliams, and Donald S. Seigel "A Theoretical and Empirical Analysis of Journal Rankings: The Case of Formal Lists” Journal of Management vol. 26, no. 5, pp. 839-861.

20. Zivney, Terry L., William J. Bertin, and Thomas A. Gavin “A Comprehensive Examination of Accounting Faculty Publishing” Issues in Accounting Education (Spring, 1995), pp. 1-10. 
Table 1-Mean Publication Rates

Panel 1-All Faculty Ranks Combined*

\begin{tabular}{llllllll} 
Specialty & All & AIS & Audit & Financial & Managerial & Tax & Other \\
\hline Total & 15.4 & 13.1 & 17.0 & 15.7 & 11.5 & 37 & 17.0 \\
$\mathrm{~N}=$ & 202 & 18 & 38 & 64 & 16.3 & 27 \\
\hline Male & 18 & 15.8 & 20.8 & 16.8 & 2.8 & 20.8 & 20.3 \\
$\mathrm{~N}=$ & 149 & 13 & 29 & 49 & 7.8 & 10 & 20 \\
\hline Female & 8.6 & 6 & 4.7 & 12.1 & 9 & 12.3 & 5 \\
$\mathrm{~N}=$ & 53 & 5 & 9 & 15 & & 8 \\
\hline
\end{tabular}

Panel 2-Assistant Professors

\begin{tabular}{llllllll} 
Specialty & All & AIS & Audit & Financial & Managerial & Tax & Other \\
\hline Total & 3.9 & 5.4 & 4.1 & 3.8 & 4.0 & 2.8 & 3.3 \\
$\mathrm{~N}=$ & 62 & 5 & 16 & 20 & 13 & 4 & 5 \\
Male & 4.8 & 3.5 & 4.6 & 4.8 & 5.2 & 9 & 0 \\
$\mathrm{~N}=$ & 36 & 2 & 10 & 13 & 1.3 & 2.8 & 1.5 \\
Female & 2.7 & 6.7 & 3.2 & 1.9 & 4 & 4 & 2 \\
$\mathrm{~N}=$ & 26 & 3 & 6 & 7 &
\end{tabular}

Panel 3-Associate Professors

\begin{tabular}{|c|c|c|c|c|c|c|c|}
\hline Specialty & All & AIS & Audit & Financial & Managerial & Tax & Other \\
\hline Total & 11.6 & 8.5 & 10.7 & 12.8 & 12.1 & 6.3 & 11.3 \\
\hline $\mathrm{N}=$ & 53 & 6 & 13 & 17 & 9 & 7 & 6 \\
\hline Male & 12.6 & 9.2 & 11.6 & 13.4 & 12.8 & 6.7 & 12.5 \\
\hline $\mathrm{N}=$ & 40 & 5 & 10 & 15 & 5 & 6 & 4 \\
\hline Female & 8.5 & 5 & 7.7 & 8.0 & 11.3 & 4 & 8.5 \\
\hline $\mathrm{N}=$ & 13 & 1 & 3 & 2 & 4 & 1 & 2 \\
\hline
\end{tabular}

\section{Panel 4-Mean Publications- Full Professors*}

\begin{tabular}{llllllll} 
Specialty & All & AIS & Audit & Financial & Managerial & Tax & Other \\
Total & 28.0 & 30.4 & 48.9 & 26.4 & 17.7 & 15 & 35.9 \\
$\mathrm{~N}=$ & 77 & 5 & 9 & 26 & 17.6 & 7 & 15 \\
\hline Male & 29.0 & 30.4 & 48.9 & 26.7 & 14 & 42.0 & 26.5 \\
$\mathrm{~N}=$ & 65 & 5 & 9 & 20 & 20 & 4 & 13 \\
\hline Female & 22.6 & & & 25.5 & 1 & 27.7 & 7.5 \\
$\mathrm{~N}=$ & 12 & 0 & 0 & 6 & & 3 & 2 \\
\hline
\end{tabular}

*Note: Two unusually high male respondents were eliminated as outliers. 
Table 2 Publication Rates Per Year After Receiving Doctorate*

Panel 1-All Faculty Ranks Combined (standard deviation = .07)

\begin{tabular}{llllllll} 
Specialty & All & AIS & Audit & Financial & Managerial & Tax & Other \\
\hline Total & 1.08 & 1.22 & 1.31 & 1.06 & .89 & .85 & .92 \\
$\mathrm{~N}=$ & 191 & 16 & 38 & 64 & 36 & 15 & 27 \\
\hline Male & 1.15 & .92 & 1.47 & 1.13 & .97 & .79 & 1.04 \\
$\mathrm{~N}=$ & 140 & 11 & 29 & 49 & 27 & 9 & 20 \\
\hline Female & .88 & 1.87 & .79 & .84 & .66 & .95 & .59 \\
$\mathrm{~N}=$ & 51 & 5 & 9 & 15 & 9 & 6 & 7 \\
\hline
\end{tabular}

Panel 2-Assistant Professors (standard deviation = .10)

\begin{tabular}{llllllll} 
Specialty & All & AIS & Audit & Financial & Managerial & Tax & Other \\
\hline Total & .92 & 2.0 & .93 & .78 & .83 & .75 & .62 \\
$\mathrm{~N}=$ & 61 & 5 & 16 & 20 & 13 & 3 & 4 \\
\hline Male & 1.00 & 1.66 & 1.03 & .92 & 1.04 & -- & .53 \\
$\mathrm{~N}=$ & 36 & 2 & 10 & 13 & 9 & 0 & 2 \\
\hline Female & .80 & 2.22 & .77 & .51 & .36 & .75 & .70 \\
$\mathrm{~N}=$ & 25 & 3 & 6 & 7 & 4 & 3 & 2 \\
\hline
\end{tabular}

Panel 3-Associate Professors (standard deviation = .08)

\begin{tabular}{llllllll} 
Specialty & All & AIS & Audit & Financial & Managerial & Tax & Other \\
\hline Total & 1.09 & .79 & 1.07 & 1.06 & 1.11 & .71 & .62 \\
$\mathrm{~N}=$ & 53 & 6 & 13 & 17 & 9 & 7 & 4 \\
\hline Male & 1.18 & .81 & 1.13 & 1.12 & 1.28 & .75 & .53 \\
$\mathrm{~N}=$ & 40 & 5 & 10 & 15 & 5 & 6 & 2 \\
Female & .80 & .71 & .84 & .61 & .89 & .44 & .70 \\
$\mathrm{~N}=$ & 13 & 1 & 3 & 2 & 4 & 1 & 2 \\
\hline
\end{tabular}

Panel 4-Full Professors (standard deviation $=.13$ )

\begin{tabular}{llllllll} 
Specialty & All & AIS & Audit & Financial & Managerial & Tax & Other \\
\hline Total & 1.20 & .69 & 2.31 & 1.26 & .81 & 1.12 & .98 \\
$\mathrm{~N}=$ & 74 & 4 & 9 & 26 & 14 & 5 & 16 \\
\hline Male & 1.22 & .69 & 2.31 & 1.26 & .80 & .87 & 1.06 \\
$\mathrm{~N}=$ & 63 & 4 & 9 & 20 & 13 & 3 & 14 \\
\hline Female & 1.14 & -- & -- & 1.28 & .95 & 1.49 & .42 \\
$\mathrm{~N}=$ & 11 & 0 & 0 & 6 & 1 & 2 & 2 \\
\hline
\end{tabular}

*Note: Two unusually high male publication rates were eliminated as outliers. 
Table 3: Linear Regressions For Faculty Publication Rates (Coefficients With T-Statistics Below)

\begin{tabular}{|c|c|c|c|c|c|c|c|c|c|c|}
\hline & & & & & & Reseal & ch areas: & & & \\
\hline Regression: & Constant & Gender & $\begin{array}{c}\text { Years } \\
\text { from } \\
\text { receiving } \\
\text { doctorate }\end{array}$ & $\begin{array}{c}\text { Ph. D. } \\
\text { offered? }\end{array}$ & Audit & Tax & $\begin{array}{l}\text { Mana- } \\
\text { gerial }\end{array}$ & $\begin{array}{c}\text { Finan- } \\
\text { cial }\end{array}$ & $\begin{array}{c}\text { Adjusted } \\
\text { R- } \\
\text { squared }\end{array}$ & $\begin{array}{l}\text { Durbin- } \\
\text { Watson } \\
\text { Statistic }\end{array}$ \\
\hline All Faculty & -6.29 & 3.36 & 1.04 & 1.90 & 4.12 & 3.48 & -2.96 & 0.87 & 0.32 & 2.08 \\
\hline$n=196$ & -1.71 & 1.56 & 8.55 & 0.88 & 1.08 & 0.57 & -1.03 & 0.27 & & \\
\hline Asst Professors & -0.54 & 1.50 & 0.48 & -1.15 & -0.18 & 1.35 & 0.61 & 1.27 & 0.25 & 2.19 \\
\hline$n=67$ & -0.30 & 2.24 & 2.34 & -1.77 & -0.16 & 0.83 & 0.57 & 1.14 & & \\
\hline Assoc Professors & -0.39 & 4.27 & 0.32 & -3.00 & 2.64 & -1.46 & 3.83 & 4.18 & 0.28 & 2.23 \\
\hline $\mathrm{n}=58$ & -0.17 & 3.17 & 2.10 & -2.13 & 1.19 & -0.83 & 1.43 & 2.11 & & \\
\hline Full Professors & -1.61 & 4.79 & 0.59 & 5.71 & 21.97 & 14.48 & -4.25 & 2.86 & 0.17 & 2.02 \\
\hline$n=71$ & -0.14 & 0.80 & 2.04 & 1.14 & 2.23 & 1.01 & -0.91 & 0.47 & & \\
\hline Numbers in bold & re significa & $t$ at the 5 & 0 level & & & & & & & \\
\hline Numbers in italics & re significat & t at the 10 & olevel & & & & & & & \\
\hline Results reflect Wh & e correction & for hetero & kedasticity & & & & & & & \\
\hline
\end{tabular}

Table 4: Linear Regressions For Selected Faculty Research Areas (Coefficients With T-Statistics Below)

\begin{tabular}{|c|c|c|c|c|c|c|}
\hline Regression: & Constant & Gender & $\begin{array}{c}\text { Years After } \\
\text { Receiving } \\
\text { Doctorate }\end{array}$ & Ph. D. Offered? & $\begin{array}{c}\text { Adjusted } \\
\text { R-squared }\end{array}$ & $\begin{array}{l}\text { Durbin- } \\
\text { Watson } \\
\text { Statistic }\end{array}$ \\
\hline All Faculty & -6.29 & 3.36 & 1.04 & 1.90 & 0.32 & 2.08 \\
\hline $\mathrm{n}=196$ & -1.71 & 1.56 & 8.55 & 0.88 & & \\
\hline Financial & -0.38 & 0.82 & 1.23 & -2.76 & 0.50 & 2.05 \\
\hline $\mathrm{n}=63$ & -0.04 & 0.20 & 6.09 & -0.08 & & \\
\hline Auditing & -13.67 & 6.21 & 1.46 & 4.42 & 0.43 & 1.74 \\
\hline $\mathrm{n}=37$ & -2.03 & 1.54 & 4.25 & 0.87 & & \\
\hline Managerial & -0.95 & 3.33 & 0.53 & -0.91 & 0.36 & 2.52 \\
\hline $\mathrm{n}=35$ & -0.22 & 1.42 & 4.03 & -0.43 & & \\
\hline \multicolumn{7}{|c|}{ Numbers in bold are significant at the $5 \%$ level } \\
\hline \multicolumn{7}{|c|}{ Numbers in italics are significant at the $10 \%$ level } \\
\hline Results reflect & correction & roskedasti & & & & \\
\hline
\end{tabular}


NOTES 